\title{
Prospective Perspective: Visual Anthropology and/as Intangible Cultural Heritage in Serbia
}

\author{
MARIJA BRUJIĆ and MILOŠ MILENKOVIĆ \\ Department of Ethnology and Anthropology, \\ Faculty of Philosophy, University of Belgrade
}

\begin{abstract}
Although only recently recognized by the Serbian government (in 2010), intangible cultural heritage constitutes an indispensable part of anthropological research programs in Serbia. We juxtapose current Serbian national and socio-anthropological practices toward ICH and discuss the importance of these practices for the safeguarding of this heritage. Furthermore, we focus on visual anthropology and visual ethnography to explore the possibilities, benefits and limitations of visual technologies in the safeguarding process. Last, we apply the idea of the humanities and social sciences as ICH (and not only the organized exploration of it) to visual anthropology in order to merge the gap between the decontextualization of ICH and its safeguarding.

Key words: intangible cultural heritage, safeguarding, visual anthropology and ethnography, Republic of Serbia, policy, social sciences and humanities as cultural heritage
\end{abstract}

\section{INTANGIBLE CULTURAL HERITAGE IN SERBIA}

Intangible cultural heritage (ICH) is alive and living heritage, which is "constantly recreated by communities and groups in response to their environments and provides them with a sense of identity and continuity", while its safeguarding serves to promote cultural diversity (UNESCO 2010: Article 2; Rusalić 2009: 11, 13, 14). It encompasses "practices, representations, expressions, knowledge, skills - as well as the instruments, objects, artefacts and cultural spaces associated therewith - that communities, groups and, in some cases, individuals recognize as part of their cultural heritage" (UNESCO 2010: Article 2). ICH disseminated via television and other media "aims at influencing the cultural memory" of people, "reflects the values and experiences of local communities and cultures [...] and is one necessary part for the preservation of cultural diversity" (Lipp 2009). Pinna (2003) defines three categories of ICH: 
1. expressions embodied in the physical form of the culture or traditional ways of life of a community

2. expressions without physical form: language, memory, oral traditions, songs and non-written traditional music

3. symbolic and metaphorical meanings of objects derived from interpretations in context

Put simply, Živković defines ICH as "national property” (Živković 2011b: 24).

\section{RECENT SERBIAN POLICIES TOWARD ICH SAFEGUARDING}

The first decade of the twenty-first century introduced the idea of promoting ICH in Serbian policies. In the Republic of Serbia (RS), a number of institutions are engaged with the research and/or protection of ICH: the Institute for the Protection of Cultural Monuments of the RS, the Central Institute for Conservation, historical and ethnographic museums, the Ethnographic and Musicology institutes and the Institute for Balkan studies of the Serbian Academy of Science and Arts, the Department of Ethnology and Anthropology at the Faculty of Philosophy in Belgrade, and the Ethnomusicology Department of the Faculty of Music in Belgrade. Other entities concerned with ICH protection include music high schools, the "Stevan Stojanović Mokranjac" ethno-music section, many NGOs, ethnographic and documentary films by the Radio Television of Serbia (RTS), and numerous individual enthusiasts (Rusalić 2009; Bižić-Omčikus 2005; Pavićević 2011; for a detailed review of the institutions and organizations that deal with ethnomusicological heritage, see Vasić 2011). ${ }^{1}$ The goal of safeguarding ICH is to stress tolerance, emphasize social cohesion and respect for differences (Živković 2011b). As in all Balkan countries, the decade was also a time of national legislation reform, and a period of introducing modern approaches to the valorisation, protection and management of culture (Rusalić 2009; see Bižić-Omčikus 2005). After the first several years of active engagement (2001-2003) - during which the Serbian Ministry of Culture organized conferences, consultations, seminars, debates, and national evaluations of cultural policy - the country still lacked appropriate legislation, institutional models and networking institutions (Rusalić 2009). However, from 2008 to 2011, the protection of

\footnotetext{
${ }^{1}$ It should be noted that in the visual field, ICH is often treated as a traditional domain of national and local television productions, which sometimes consult ethnologists and anthropologists in their work. We looked through the programs of the 9-19th International Festival of Ethnological Film, held in Belgrade from 2000 to 2008. We also looked at the programs from 2009 and 2010, but these did not contain detailed credits. After reviewing all programs, we found the following: out of a total of 291 Serbian-produced films, 133 had an "expert consultant". The term seems dubious, but it can be said that less than ten films were made by Serbian ethnologists and anthropologists or co-produced by them.
} 
cultural material and intangible heritage was set as a strategic priority by the Serbian Ministry of Culture. In May 2010, the Ministry ratified the Convention for the Safeguarding of the Intangible Cultural Heritage and officially recognized the significance of Serbian ICH, its protection and its role in the economic development of the country (Zakon 2011; Krause 2011; "Bradić: Nematerijalnu kulturnu..." 2010). This was followed by the establishment of an interdisciplinary network for the safeguarding of ICH, which consists of the National Committee for ICH, the Commission for Inscription in the National Registry of ICH, the Centre for Intangible Cultural Heritage Studies at the Ethnographic Museum in Belgrade and the Development Education Centre for ICH in the village of Sirogojno. The network documents, researches, protects, safeguards and transmits ICH as defined by UNESCO (Živković 2011b), ${ }^{2}$ and has many functions. For instance, it elaborates the safeguarding strategy of ICH in Serbia, participates in national legislation processes, determines the criteria and methodology for the national registration process, surveys the national system for UNESCO programs, and coordinates national and regional programs, projects and research (Živković 2011b; see also Srećković 2011 and Tomić-Joković 2011). The main goal of the network is to compile a national inventory, a list of ICH requiring urgent safeguarding, and to create a system to protect and continue the transmission of cultural heritage, which includes consulting living culture bearers (Inđić 2011). According to Trivo Inđić, Serbia's president of the National Commission for UNESCO, despite the fact that these policies and practices are in their earliest stages, they are well organized and up to date. He further emphasizes that the important aspects of ICH safeguarding in Serbia include research on and development of cultural identity and cultural heritage, particularly regarding the cultural, ethnic, linguistic and religious multivocality of Serbia's various traditions (ibid.). Following these practices, Dušica Živković, former Assistant Minister in charge of cultural heritage and current President of the National Committee for the Safeguarding of the Cultural Intangible Heritage of Serbia, declared in her editorial speech that the Serbian Ministry of Culture and Information, in cooperation with the Centre for Intangible Cultural Heritage Studies, launched the (partly bilingual) journal Intangible Cultural Heritage of Serbia. The aim of the journal is to address issues in ICH preservation, and give practical and technical information to experts and local people: "to understand its value and the importance of its preservation" with an aim to preserve cultural diversity (Živković 2011a: 4). It is within this enthusiastic framework that Serbian ethnologists and anthropologists enter the context of researching and protecting intangible cultural heritage.

${ }^{2}$ Available at: http://www.seecult.org/vest/otvoren-centar-za-nematerijalno-kulturno-naslede-srbije and http://www.seecult.org/vest/promocija-konvencije-o-nematerijalnom-kulturnom-nasledu. 


\section{ETHNOLOGY, ANTHROPOLOGY AND ICH IN THE SERBIAN ACADEMIA}

In Serbia, programs in ethnology and anthropology/socio-cultural anthropology are offered only at the University of Belgrade's Faculty of Philosophy, the Department of Ethnology and Anthropology. In Belgrade, the first course in ethnology was introduced in 1881 and the Ethnological Seminar was established in 1906 at the Faculty of Philosophy. ${ }^{3}$ Despite the fact that, for a long time, ICH had not been recognized by Serbian government policies as an important legacy to be protected, it is simultaneously an indispensable part of anthropological research in Serbia. Ethnologists and anthropologists (hereafter anthropologists) explore cultural expressions, social practices, customs, traditional knowledge, languages, cultural landscapes, music, beliefs, social and artisan traditions, and they explore their meanings in specific historical and socio-cultural contexts (Rusalić 2009; see Žikić 2006; Bižić-Omčikus 2009; UNESCO 2010; and Gavrilović 2011). Within the Department of Ethnology and Anthropology, several courses offered on various levels of study focus on the research of ICH; for instance, on visual and cognitive anthropology, and the anthropology of folklore (see Žikić 2006 for a cognitive anthropology approach). ${ }^{4}$ Currently, the Ministry of Culture, the University's Department of Ethnology and Anthropology and the Ethnological and Anthropological Society of Serbia successfully collaborate on several projects and conduct research for the "qualitative mapping, understanding, protection and promotion of ICH in Serbia" (Sinani 2012: 44).

Anthropologists are constantly faced with a paradox that lies in the nature of ICH safeguarding: How is it possible to protect the nature of ICH if it is in constant change? Safeguarding measures should not fix heritage, and anthropology, with its care for culture as a living and evolving process as opposed to the concept of culture as a stable and invariant whole, seems theoretically reluctant to the idea of protection altogether. Živković (2011b) explains that intangible heritage is on the one hand endangered by globalization and homogenization processes and, on the other, by safeguarding measures that can petrify it. The only inherent element of ICH is its changing nature. Intangible cultural heritage should be subject to interpretations and changes by its users and those who carry it from generation to generation and, thus, should be protected with regard to its changing nature and not merely preserved (ibid.). In other words, "protection should ensure the life of

\footnotetext{
${ }^{3}$ Available at: http://www.f.bg.ac.rs/en2/ethnology_anthropology/about.

${ }^{4}$ See the following curricula: http://www.f.bg.ac.rs/en2/ethnology_anthropology/program_predmet_eng.php?IDK=2898\&SP=308; http://www.f.bg.ac.rs/en2/ethnology_anthropology/program_predmet_eng.php?IDK=2929\&SP=358; http://www.f.bg.ac.rs/en2/ethnology_anthropology/program_predmet_eng.php?IDK=2021\&SP=358.
} 
the process not of the product" (ibid.: 23). ICH should not be artificially maintained or used for the indoctrination of younger generations (Sinani 2012) if it safeguards rituals they have never used and that live only in the past. Social scientists should thus avoid conserving not only heritage but also identities that heritage supposedly petrifies. With regard to the UNESCO Convention, the safeguarding of ICH intersects with the regular, self-perceived task of trained anthropologists. In this respect, Gavrilović (2011) makes several important points. First, the author warns of the practice of equating protection (and possibly essentialization) of intangible heritage with the protection of communities, pointing out that ICH protection is and should be understood as a case-sensitive and arbitrary choice. ${ }^{5}$ Arguing for glocalization as the only possible way of preserving both material and immaterial tradition, which remains invisible in the Convention's application, she takes the protection of ICH as a "global strategy for preserving cultural diversity", which should engender culturally defined identities as well as globalized and glocalized cultural variations (ibid.: 56). Although not prevalent, this view serves as a cornerstone for synthesizing the research and protection of ICH within the growing community of Serbian anthropologists working in this domain.

\section{VISUAL ANTHROPOLOGY: SCOPES FOR ICH SAFEGUARDING}

\section{LIMITS AND POTENTIAL OF VISUAL ANTHROPOLOGY AND VISUAL ETHNOGRAPHY}

"Visual anthropology is a multidisciplinary field that joins the arts and the humanities with the social and biological sciences" through an interest in human expression and communication of culture (Strong 2009: 1-2). In short, visual anthropology can serve as a research method (of documenting and collecting data) and as a subject of a research (when a visual methodology is a research theme). MacDougall (1998) defines visual anthropology as a research technique, field of study, teaching tool, means of publication, and another approach to anthropological knowledge. Similarly, for Westermann (2005), visual anthropology critically analyzes visual methods of anthropological documentation and research into the visual production of cultures. Morphy and Banks in their introduction to Rethinking Visual Anthropology, define visual anthropology as "the anthropology of visual systems or, more broadly, visible cultural forms" (1999: 5). The authors give a twofold explanation of visual anthropology - it is "the use of visual material in anthropo-

${ }^{5}$ Gavrilović gives several heritage examples, such as stories of vendetta, which are excluded from UNESCO's protection. 
logical research", 6 and "the study of visual systems and visual culture, it both produces visual texts and consumes them" (ibid.: 1-2).

One way to observe intangible culture is by using our visual and aural senses. Since visual anthropology and visual ethnography (see Pink 2001) - most prominently through ethnographic films - record and communicate anthropological knowledge (see Ruby 2000), is it unreasonable to ask if and how they could convey anthropological knowledge about intangible cultural heritage? To put it simply, both visual anthropology and ethnography ${ }^{7}$ include many possibilities for improving ICH safeguarding. They can visually document the intangible cultural aspects and sometimes their methods are more powerful than words. As MacDougall (1999) notes, synaesthesia and metaphor are best conveyed via visual media. In many cases, visual anthropology combined with other approaches or disciplines should be an indispensable asset for ICH safeguarding. In hindsight, visual (and also socio-cultural) anthropology was long understood only as a research tool for documenting and preserving the world's disappearing customs, rituals, practices, types of behaviour and other socio-cultural elements and human traits. In this manner, visual anthropology is equated more with "old-school" ethnography - with its perceived goal to document disappearing rituals, traits, etc. in a world that is drastically changing - than with scientific research (for the preliminary perspective on this, see Mead 1995). However, as Sorenson reminds us, "the change is inevitable"; he criticizes mimicking customs as a teaching tool to re-establish our heritage: "At its worst it encourages people to remain in the backwash of history; at its best it gives moments of nostalgia to the old folks" (1995: 495-496). Sinani, in a similar vein, argues against the "artificial revival of intangible customs" (2012: 52). In accordance with these points, visual anthropology is not an "all-powerful" discipline and, in order to improve their investigations, researchers should be aware of its limitations. As Asch and Asch remark, visual data are not "a reflection of reality" but are a human product, created at a specific moment in time and space, from specific cultural, political, economic and institutional perspectives (1995: 338). While it is reasonable to say that film, as one of the main elements of visual anthropology, "captures an external reality for future analysis in many contexts", and that "ethnographic account captures knowledge about that reality" (Hockings 1995: 515), neither visual anthropologists nor visual anthropology is devoid of problems. Similarly to the other

\footnotetext{
${ }^{6}$ For discussions on the use of visual sources in ethnology and anthropology, see Gavrilović (2004); Naumović (1988) and Prošić-Dvornić (1982).

${ }^{7}$ We thank Dr. Naško Križnar from the Slovenian Academy of Sciences and Arts for pointing out that, generally speaking, for ICH safeguarding, visual ethnography is more applicable than visual anthropology (Round Table: Centre for Intangible Cultural Heritage of Serbia - New Perspectives in the Development of Visual Anthropology, Belgrade, 21st International Festival of Ethnological Film, 12 October 2012).
} 
social sciences and humanities, visual anthropology and visual ethnography are loaded with issues regarding decontextualization, the interpretation of data, and ethics related to their research and presentation. Pink stresses that film- and photo-making of informants can be ethically inappropriate (2001: 33 ). Although visual anthropology is a young anthropological sub-discipline, it investigated ICH long before the term was coined. Thus, possible applications of visual anthropology and visual technologies in the field of ICH can be equated with the potential of visual anthropology in general, and these recommendations should be read in this light. Visual anthropology, visual ethnography and ethnographic films can serve as "a source of data of passing forms of human behavior and organization" (Sorenson 1995: 494). Visual technologies can be used in teaching, fieldwork and research; to archive, interpret and analyze cultural material; and to communicate with research participants or the wider public (Hockings 1995; Rouch and Hockings 1995; Strong 2009; Pink 2001; Križnar 2009). According to Paul Hockings, writing about ethnographic filmmaking brings anthropology closer to the attention of the public (1995: 508). Moreover, this potential of visual recording can be used in ICH safeguarding. Visual ethnography and international ethnographic film festivals can bring ICH not only to the public's attention, but also to the awareness of potential investors and sponsors. Furthermore, Sarah Pink emphasizes the importance of "electronic hypermedia"8 in the future of visual anthropology. According to her, photographs, videos and other visual media are "cultural texts and representations of ethnographic knowledge" (2001: 1 ). She argues for the use of hypermedia as a way to merge the gap between visual representations and mainstream anthropology. While electronic hypermedia can be used as "sites of cultural production" and thus as a research topic themselves, they are also tools for the "production, representation and viewing of ethnographic materials" (ibid.: 1, 155). For example, ethnographic clips prove useful in conferences and other types of presentations. She also proposed electronic hypermedia for publishing ethnographic works (online journals, websites, CD-ROM and DVD publications and projects) (ibid.; Pink 2004b). Electronic hypermedia should

exist as research resources, presenting field notes, photographs and film clips, as reflexive texts and as materials other researchers might interrogate [...] With its potential to be multimedia, multilinear, multivocal, interactive and reflexive, hypermedia clearly does satisfy many of the demands currently put on not only visual ethnography but on ethnography in general. (Pink 2004a: $5-6)$

${ }^{8}$ The author defines electronic hypermedia publications as a combination of interactive interlinked files with still or moving images and written text (Pink 2001; Pink 2004b). 


\section{THE ROLE OF VISUAL ANTHROPOLOGY WITHIN ICH SAFEGUARDING}

Apart from the fact that the concept of intangible heritage is mainly associated with "traditional" culture, ICH regularly occurs in present-day time and thus represents contemporary manifestations of communities' cultural belonging (Todorović 2011: 77). Thus, can visual anthropology assist in improving ICH safeguarding? If so, how? Our study of the topic has shown that there are not many articles dedicated to it. ${ }^{9}$ Lipp states that ICH offers several possibilities for the improvement of visual anthropology; conversely, visual anthropology offers possibilities for ICH protection. The author argues for an "Intangible Heritage Media Institute", which would be based on the principles of multivocality (several narratives and/or aesthetic concepts, several authors from different cultural backgrounds), multisitedness (contributing institutions located in several places), empowerment (of media professionals, media artists, indigenous filmmakers, visual anthropologists), experimentation (experimental explorations of narrative forms), cooperation and co-production (a joint project of media professionals and artists, indigenous filmmakers and visual anthropologists) (2009: 87-89). Consequently, this could decrease the limitations of visual anthropology and be more reflexive. While a reflexive approach is not at all new in anthropology and is in fact an established methodological tool embedded in the research process itself (see Milenković 2006 for an account), Lipp's "Intangible Heritage Media Institute" represents one possible solution for improving the relationship between visual anthropology and the subject of intangible culture. The author also warns against the conversion of ICH into a "folklorized art piece" (ibid.: 87). Lipp suggests that the main goal of visual anthropology should be "to collect, produce and distribute audiovisual adaptations of the UNESCO Intangible Heritage over internet, DVD and television. At the same time, ongoing research will be car-

\footnotetext{
${ }^{9}$ In her introduction, Sarah Pink (2007) stresses the importance of applied visual anthropology, and in the same volume, Yiakoumaki (2007) presents a European Commission sponsored visual ethnographic study about the intangible cultural heritage of Mediterranean urban culture as an example of applied visual anthropology. Pink distinguishes between academic visual anthropology and applied visual anthropology. According to her, academic visual anthropology is "more exploratory and less problem solving", while applied visual anthropology seeks to achieve non-academic ends using academic theory, methodology and practice by social intervention and collaboration with research participants, which results in changing their lives (2007: 6, 12). Regarding such a practice in the case of ICH safeguarding, however, we disagree with the concept of "applied visual anthropology". Visual anthropology and ethnography are involved in the lives of others. Anthropologists intervene in the lives of their research participants (especially the ones holding the camera) and spend a lot of time with them, consequently changing their lives in one way or another. There were debates about these issues within the field of visual anthropology long before the term "applied visual anthropology" was coined (for discussion on the difference between "indigenous media", "participatory" film (video) making, and "community" video/ broadcasting, see Aufderheide (1995); Chalfen (1989); Downmunt (1993); Faris (1992; 1993); Ginsburg (1991; 1994); Elder (1995); and Turner (1992). For visual methods, see Banks (1995).
} 
ried out as to how this picturing culture undertaking can be refined" (ibid.: 89). To paraphrase Lewis Carroll's character Humpty Dumpty, "who will be the master of words?" In the case of ICH safeguarding, the question can be rephrased. Importance lies less with who will be the master of the heritage tradition, but more with who has the final word in deciding which particular traditions will be documented. Laura Graham is reflective about these issues and notes that researchers should be mindful of "who decides what will be documented; whose interests the safeguarding serve[s] and what [...] the purpose for documenting cultural forms in specific cases [is]" (2009: 185). Documenting ICH is a double-edged sword. She explains the contradictions of (audiovisual, written and audio) recording processes:

While field recordings enable broader audiences to gain a richer sense of performance, as embodied practice beyond what is apparent in written texts, they nevertheless remove expressive performances from their original contexts [...] Decontextualization is an extractive process that inevitably removes elements [...] for local participants and audiences [...] Thus, while documentary processes may open up access for new and often remote audiences, they are never complete replicas of original events; elements that are essential to local meanings may be lost. (2009: 188)

Using examples of safeguarding native communities' intangible heritage, Graham further explains that the use of modern technologies in these communities can additionally reinforce or perpetuate power and dependency relations; she thus argues for local control and participation of local communities in all aspects of media production (2009: 191-199; see also Engelhardt 2005).

\section{VISUAL ANTHROPOLOGY AS INTANGIBLE CULTURAL HERITAGE: A PRELIMINARY ACCOUNT}

Several Serbian anthropologists point to the significance of the social sciences and humanities with regard to ICH, due to their identity-oriented scope of research. They see these areas of study, in the narrow sense, as a peculiar part of intangible cultural heritage (Milenković 2010; Sinani 2012). As Milenković stresses, "the rituals, artefacts, and beliefs, self-understanding, etc. are irrelevant without the context of their application" (2010: 181). Sinani extends this idea by saying that the social sciences, with their long tradition of studying intangible culture, represent the "largest corpus of data and knowledge about it" (2012: 53). In this respect, ethnology and anthropology, as culture- and identity-oriented sciences, can be understood not 
only as a research endeavour but also as a heritage - seen as a specific form of intangible cultural heritage (Žikić 2012; Milenković 2010). Žikić explains this idea by using the example of ethnology and anthropology practices that "deal with human physical and metaphysical organization of the world in order to provide understandings of culture". In this respect, cultural identity is an element of cultural heritage of a community as well as the "social and cultural relationship that a human community has towards these artefacts" (Žikić 2012: 10-11). The community's self-perception depends on the valuation, connotation and significance given to these artefacts. The process of constructing cultural identity is connected to material and immaterial qualities that are considered to belong to the group. In this respect, cultural identification is a symbolic process, which includes the cultural awareness that "what makes us a member of a community is a particular intangible quality" (ibid.: 11). Within this context of reinterpreting the qualities and properties of anthropological work in general, it is possible to interpret the roles of visual anthropology and visual ethnography not only as tools and fields of study for intangible cultural heritage but also as a specific type of ICH; i.e. it is not only their products, like ethnographic films, that can be taken as part of cultural heritage (Hockings 1995), but the discipline as a whole, with its analyses and interpretations, should be included. In this manner, the gap between safeguarding the elements of intangible culture and their possible decontextualization during this process can be merged - by reflexive acceptance of the visual anthropologist's constitutive role in the documentation and analysis of intangible cultural heritage.

\section{FINAL REMARKS}

In this paper, we summarized Serbia's current situation regarding intangible heritage elements and their safeguarding, and that of ethnology and anthropology, specifically visual anthropology.

Due to their visual and audio nature, visual anthropology and ethnography offer considerable potential for the exploration of intangible culture, especially with the widespread and easy use of visual technologies among the public. Morphy and Banks explain this situation: "visual anthropology is [...] a reminder that much that is observable, much that can be learned about culture can be recorded most effectively and comprehensively through film, photography or by drawing" (1999: 14). At the same time, it should not be dismissed that while much is observable and can be learned about culture, local communities may hide significant realities from the eyes of the camera. While Rusalić suggests making an ethnological films archive "that would be 
produced on purpose primarily in order to preserve traditional knowledge, skills, ritual and social practices", we suggest the complete opposite (2009: 119). Visual anthropologists, equipped with socio-constructivist understandings of cultural phenomena, such as "culture", "identity", and "ethnicity" should problematize ICH, since it is easy to slip into this essentialism. In addition, Pink (2004a: 2) emphasizes the importance of "visual ethnography that is informed by anthropological theory and embedded in anthropological research questions". She proposes interactive hypermedia for the presentation and analysis of media and written text that are accessible to both researchers and the public. In this manner, petrifaction of culture and its elements would (hopefully) be avoided and instead would be envisaged as processes susceptible to change. Strategically and institutionally speaking, ICH safeguarding presents an innovative perspective in the development of visual anthropology and vice versa.

Finally, we would like to emphasize that although the elements of intangible culture were the subject of ethnological and anthropological study in the Republic of Serbia long before the ratification of the UNESCO Convention, this, not necessarily academic, novel platform of support for institutional and regional cooperation assures that this research should and will be continued and improved.

\section{NOTES}

This article is the result of work on the project Identity Politics of the European Union: The Adaptation and Application in the Republic of Serbia (177017) funded by the Ministry of Education, Science and Technological Development of the Republic of Serbia.

Some of the ideas in this paper were presented during two round tables dedicated to the role of visual anthropology in ICH safeguarding in 2012: Methods of visual anthropologic in collecting and interpreting intangible culture and relevant cultural politics in South Eastern Europe (Rovinj, Croatia, ethnographic film festival events, ETNOFILm); and Centre for Intangible Cultural Heritage of Serbia - new perspectives in the development of visual anthropology (Belgrade, Serbia, International Festival of Ethnological Film).

\section{REFERENCES AND SOURCES}

Asch, Timothy and Patsy Asch. 1995. "Film in Ethnographic Research". In Principles of Visual Anthropology. Paul Hockings, ed. Berlin, New York: Mouton de Gruyter, 335-360. [http:// dx.doi.org/10.1515/9783110290691.335]

Aufderheide, Patricia. 1995. "The Video in the Villages Project. Videomaking with and by Brazilian Indians". Visual Anthropology Review 11/2: 83-93. [http://dx.doi.org/10.1525/ var.1995.11.2.83]

Banks, Marcus. 1995. "Social Research Methods". Social Research Update 11. Available at: http://sru.soc.surrey.ac.uk/SRU11/SRU11.html (accessed 1 October 2012). 
Bižić-Omčikus, Vesna. 2005. "Nematerijalna kulturna baština i Etnografski muzej u Beogradu”. Glasnik Etnografskog muzeja 69: 147-160.

Bižić-Omčikus, Vesna. 2009. "Nematerijalna kulturna baština". Available at: http://www. seecult.org/blog/1620/nematerijalna-kulturna-bastina (accessed 5 February 2012).

Chalfen, Richard. 1989. "Native Participation in Visual Studies. From Pine Springs to Philadelphia”. In Eyes Across the Water. R. M. Boonzajer Flaes, ed. Amsterdam: Het Spinhuis, 71-79.

Dowmunt, Tony. 1993. "Introduction". In Channels of Resistance. Global and Local Empowerment. Tony Dowmunt, ed. London: BFI/Channel Four, 1-15.

Elder, Sarah. 1995. "Collaborative Filmmaking. An Open Space for Making Meaning, a Moral Ground for Ethnographic Film". Visual Anthropology Review 11/2: 94-101. [http://dx.doi. org/10.1525/var.1995.11.2.94]

Engelhardt, Richard A. 2005. "Safeguarding Intangible Heritage. Cultural Industries and the Cultural Diversity Lens". Paper presented at the International Workshop of Local Government Administrators for Safekeeping of the Intangible Cultural Heritage, June 8-11, 2005, Gangneung, Republic of Korea. Available at: http://www.unescobkk.org/fileadmin/user_ upload/culture/Resources_Thailand/more/Safeguarding_Intangible_Heritage.pdf.

Faris, James C. 1992. "Anthropological Transparency. Film, Representation and Politics". In Film as Ethnography. Peter I. Crawford and David Turton, eds. Manchester: Manchester University Press, Granada Centre for Visual Anthropology, 171-182.

Faris, James C. 1993. “A Response to Terence Turner”. Anthropology Today 9/1: 12-13. [http:// dx.doi.org/10.2307/2783336]

Gavrilović, Ljiljana. 2004. Balkanski kostimi Nikole Arsenovića. Beograd: Srpska akademija nauka i umetnosti, Etnografski institut.

Gavrilović, Ljiljana. 2011. “Potraga za osobenošću. Izazovi i dileme unutar koncepta očuvanja i reprezentovanja nematerijalnog kulturnog nasleđa”. Intangible Cultural Heritage of Serbia 1: $50-57$.

Ginsburg, Faye. 1991. "Indigenous Media. Faustian Contract or Global Village?" Cultural Anthropology 6/1: 92-112. [http://dx.doi.org/10.1525/can.1991.6.1.02a00040]

Ginsburg, Faye. 1994. "Culture/Media. A Mild Polemic". Anthropology Today 10/2: 5-15. [http://dx.doi.org/10.2307/2783305]

"Bradić: Nematerijalnu kulturnu baštinu na listu UNESKO". 2010. Glas javnosti [online], 23 May 2010. Available at: http://www.glas-javnosti.rs/clanak/kultura/glas-javnosti-23-05-2010/bradic-nematerijalnu-kulturnu-bastinu-na-listu-unesko (accessed 1 February 2012).

Graham, Laura R. 2009. "Problematizing Technologies for Documenting Intangible Culture. Some Positive and Negative Consequences". In Intangible Heritage Embodied. D. Fairchild Ruggles and Helaine Silverman, eds. London, New York: Springer, 185-200. [http://dx.doi. org/10.1007/978-1-4419-0072-2_10]

Hockings, Paul. 1995. "Conclusion. Ethnographic Filming and Anthropological Theory". In Principles of Visual Anthropology. Paul Hockings, ed. Berlin, New York: Mouton de Gruyter, 507-529. [http://dx.doi.org/10.1515/9783110290691.507]

Inđić, Trivo. 2011. "Poslovi nacionalnog komiteta za nematerijalno kulturno nasleđe 2021". Intangible Cultural Heritage of Serbia 1: 20-21.

Krause, Anthony. 2011. "The 2003 Convention for the Safeguarding of Intangible Cultural Heritage. Challenges and Perspectives, 2011". Intangible Cultural Heritage of Serbia 1: 15-19.

Križnar, Naško. 2009. "Podobe kulture v vizualni etnografiji”. Bulletin of the Institute of Ethnography 57/2: 131-140. 
Lipp, Thorolf. 2009. "Picturing Intangible Heritage. Challenge for Visual Anthropology. Vision of an Intangible Heritage Media Institute". In Sharing Cultures 2009: International Conference on Intangible Heritage. Sérgio Lira, Rogério Amoêda, Cristina Pinheiro, João Pinheiro and Fernando Oliveira, eds. Barcelos: Green Lines Institute for Sustainable Development, 81-90.

MacDougall, David. 1998. Transcultural Cinema. Princeton, New Jersey: Princeton University Press.

MacDougall, David. 1999. “The Visual in Anthropology”. In Rethinking Visual Anthropology. Marcus Banks and Howard Morphy, eds. New Haven, London: Yale University Press, 276295.

Mead, Margaret. 1995. "Visual Anthropology in a Discipline of Words". In Principles of Visual Anthropology. Paul Hockings, ed. Berlin, New York: Mouton de Gruyter, 3-10. [http:// dx.doi.org/10.1515/9783110290691.3]

Milenković, Miloš. 2006. “Šta je (bila) antropološka refleksivnost? Metodološka formalizacija”. Etnoantropološki problemi n.s. 1/2: 157-184.

Milenković, Miloš. 2010. Ka politici srpske antropologije za XXI vek. Beograd: Srpski genealoški centar, Odeljenje za etnologiju i antropologiju Filozofskog fakulteta.

Morphy, Howard and Marcus Banks. 1999. "Rethinking Visual Anthropology". In Rethinking Visual Anthropology. Marcus Banks and Howard Morphy, eds. New Haven, London: Yale University Press, 1-35.

Naumović, Slobodan. 1988. “Pitanje vizuelne građe u etnologiji”. Etnološke sveske 9: 113-123.

Pavićević, Tihana. 2011. "Skup o promociji nematerijalnog kulturnog nasleđa”. Available at: http://glassrbije.org/index.php?option=com_content\&task=view\&id=102359\&Item $\mathrm{id}=30$ (accessed 10 January 2013).

Pinna, Giovanni. 2003. "Intangible Heritage and Museums". ICOM News 4. Available at: http:// icom.museum/fileadmin/user_upload/pdf/ICOM_News/2003-4/ENG/p3_2003-4.pdf (accessed 10 February 2012).

Pink, Sarah. 2001. Doing Visual Ethnography. Images, Media and Representation in Research. London et al.: SAGE Publications.

Pink, Sarah. 2004a. "Situating Visual Research". In Working Images. Visual Research and Representation in Ethnography. Sarah Pink, László Kürtl and Ana Isabel Alfonso, eds. London, New York: Routledge, 1-12.

Pink, Sarah. 2004b. "Conversing Anthropologically. Hypermedia as Anthropological Text". In Working Images. Visual Research and Representation in Ethnography. Sarah Pink, László Kürtl and Ana Isabel Alfonso, eds. London, New York: Routledge, 164-181.

Pink, Sarah. 2007. "Applied Visual Anthropology. Social Intervention and Visual Methodologies". In Visual Interventions. Applied Visual Anthropology. Sarah Pink, ed. New York, Oxford: Berghahn Books, 3-28.

Prošić-Dvornić, Mirjana. 1982. "Mogućnosti korišćenja fotografije u proučavanju materijalne kulture”. Etnološke sveske 4: 94-108.

Rouch, Jean and Paul Hockings. 1995. "Resolution on Visual Anthropology [1973]". In Principles of Visual Anthropology. Paul Hockings, ed. Berlin, New York: Mouton de Gruyter, 533-534.

Ruby, Jay. 2000. Picturing Culture. Explorations of Film and Anthropology. Chicago, London: The University of Chicago Press.

Rusalić, Dragana. 2009. Making the Intangible Tangible. The New Interface of Cultural Heritage. Belgrade: Serbian Academy of Science and Art. 
Sinani, Danijel. 2012. "Religija, kulturni identiteti i nematerijalna kulturna baština". In Kulturni identiteti kao nematerijalno kulturno nasleđe. Zbornik radova sa naučnog skupa Kulturni identiteti u XXI veku. Bojan Žikić, ed. Beograd: Srpski genealoški centar, Odeljenje za etnologiju i antropologiju Filozofskog fakulteta u Beogradu, 43-56.

Sorenson, Richard, E. 1995. "Visual Records, Human Knowledge, and the Future”. In Principles of Visual Anthropology. Paul Hockings, ed. Berlin, New York: Mouton de Gruyter, 493-506.

South East European Heritage Network. 2010. "Promotion of the Convention for the Safeguarding of the Intangible Cultural Heritage". Available at: http://www.seecult.org/vest/promocija-konvencije-o-nematerijalnom-kulturnom-nasledu (accessed 8 February 2012).

South East European Heritage Network. 2012. "The Opening of the Center for Intangible Cultural Heritage Studies". Available at: http://www.seecult.org/vest/otvoren-centar-za-nematerijalno-kulturno-naslede-srbije (accessed 5 October 2012).

Srećković, Saša. 2011. "Zaključci radionice na regionalnom seminaru o nematerijalnom kulturnom nasleđu u Sirogojnu". Intangible Cultural Heritage of Serbia 1: 72-75.

Strong, Mary. 2009. “Introduction”. In Viewpoints. Visual Anthropologists at Work. Mary Strong and Laena Wilder, eds. Austin: University of Texas Press, 1-7.

Todorović, Jelena. 2011. "Razumevanje nematerijalnog kulturnog nasleđa”. Intangible Cultural Heritage of Serbia 1: 76-79.

Tomić-Joković, Snežana. 2011. "Edukativne radionice u oblasti nematerijalnog kulturnog nasleđa". Intangible Cultural Heritage of Serbia 1: 80-87.

Turner, Terence. 1992. "Defiant Images. The Kayapo Appropriation of Video". Anthropology Today 8/6: 5-16. [http://dx.doi.org/10.2307/2783265]

UNESCO. 2010. Basic Texts of the 2003 Convention for the Safeguarding of the Intangible Cultural Heritage. Oxford: Baseline Arts.

University of Belgrade. Faculty of Philosophy. "About the Department of Ethnology and Anthropology". Available at: http://www.f.bg.ac.rs/en2/ethnology_anthropology/about (accessed 20 April 2012).

University of Belgrade. Faculty of Philosophy. "Cognitive and medical anthropology (curriculum)". Available at:http://www.f.bg.ac.rs/en2/ethnology_anthropology/program_predmet_eng.php?IDK=2021\&SP=358 (accessed 17 February 2012).

University of Belgrade. Faculty of Philosophy. "Anthropology of folklore (curriculum)". Available at: http://www.f.bg.ac.rs/en2/ethnology_anthropology/program_predmet_eng. php?IDK=2898\&SP=308 (accessed 17 February 2012).

University of Belgrade. Faculty of Philosophy. "Visual anthropology and field research (curriculum)". Available at: http://www.f.bg.ac.rs/en2/ethnology_anthropology/program_predmet_eng.php?IDK=2929\&SP=358 (accessed 18 February 2012).

Vasić, Olivera. 2011. “Nematerijalna kultura - kako je zaštititi?” Intangible Cultural Heritage of Serbia 1: 104-106.

Westermann, Mariet. 2005. "Introduction. The Objects of Art History and Anthropology". In Anthropologies of Art. M. Westermann, ed. Williamstown, Massachusetts: Sterling and Francine Clark Art Institute, vii-xxxi.

Yiakoumaki, Vassiliki. 2007. 'Archiving 'Heritage', Reconstructing the 'Area'. Conducting Audiovisual Ethnography in EU-sponsored Research". In Visual Interventions. Applied Visual Anthropology. Sarah Pink, ed. New York, Oxford: Berghahn Books, 143-176.

Zakon o potvrđivanju Konvencije o očuvanju nematerijalnog kulturnog nasleđa. 2011. Available at: http://www.kultura.gov.rs/sites/default/files/documents/Konvencija_o_ocuvanju_nematerijalnog_kulturnog_nasledja.pdf (accessed 12 January 2012). 
Žikić, Bojan. 2006. "Kognitivna antropologija i nematerijalna kutlurna baština". Glasnik Etnografskog muzeja 70: 11-23.

Žikić, Bojan. 2012. "Kulturni identiteti kao nematerijalno kulturno nasleđe. Uvod u istraživanje i preliminarni rezultati". In Kulturni identiteti kao nematerijalno kulturno nasleđe. Zbornik radova sa naučnog skupa Kulturni identiteti u XXI veku. Bojan Žikić, ed. Beograd: Srpski genealoški centar, Filozofski fakultet, Odeljenje za etnologiju i antropologiju, 7-25.

Živković, Dušica. 2011a. "Predgovor". Intangible Cultural Heritage of Serbia 1: 4-5.

Živković, Dušica. 2011b. "Implementacija Konvencije o očuvanju nematerijalnog kulturnog nasleđa u Republici Srbiji”. Intangible Cultural Heritage of Serbia 1: 22-25.

\section{PROSPEKTIVNA PERSPEKTIVA: VIZUALNA ANTROPOLOGIJA I/KAO NEMATERIJALNA KULTURNA BAŠTINA U SRBIJI}

\section{SAŽETAK}

Premda je srpska vlada tek 2010. godine priznala nematerijalnu kulturnu baštinu kao pojam, ona je nezaobilazan dio antropoloških istraživačkih programa u Srbiji. U ovome radu uspoređujemo postojeće srpske nacionalne i socioantropološke prakse prema nematerijalnoj kulturnoj baštini te raspravljamo o važnosti tih praksi za očuvanje same baštine. Nadalje, kroz prizmu vizualne antropologije i vizualne etnografije proučavamo mogućnosti, prednosti i ograničenja korištenja vizualnih tehnologija u postupku očuvanja te baštine. Najzad, na vizualnu antropologiju primjenjujemo shvaćanje humanističkih i društvenih znanosti kao nematerijalne kulturne baštine (a ne samo kao organiziranog istraživanja te baštine), čime nadilazimo jaz između dekontekstualizacije nematerijalne kulturne baštine i njezina očuvanja.

Ključne riječi: nematerijalna kulturna baština, očuvanje, vizualna antropologija i etnografija, Republika Srbija, politika, društvene i humanističke znanosti kao kulturna baština 